\title{
Usaha Peternakan Sapi Perah dan olahan susu 'Nursi'di Kecamatan Enrekang Kabupaten Enrekang Melalui Pemanfaatan Limbah Pertanian
}

\author{
The utilization of Agricultural by-products on the dairy cow farm 'Nursi' in Kecamatan \\ Enrekang Kabupaten Enrekang \\ Amriana Hifizah*, Faikatushalihat, Astati, Muhammad Arsan Jamili \\ Jurusan Ilmu Peternakan Fakultas Sains dan Teknologi \\ Universitas Islam Negeri Alauddin, Gowa-92113 \\ Sulawesi Selatan, Indonesia \\ *Korespondensi: Email:amriana.hifizah@uin-alauddin.ac.id
}

\begin{abstract}
ABSTRAK
Karya tulis ini merupakan ringkasan laporan kegiatan lapangan pada peternakan sapi perah di Kecamatan Enrekang, Kabupaten Enrekang. Usaha peternakan ini menjadi contoh bagi pengusaha ternak lainnya di daerah tersebut, karena memanfaatkan limbah pertanian berupa ampas tahu dan jerami jagung. Ampas tahu dan dedak digunakan sebagai konsentrat, lalu jerami jagung sebagai pakan alternatif pengganti pakan basal saat persediaan hijauan tidak mencukupi. Kegiatan ini bertujuan untuk mengetahui sejauh mana pemanfaatan limbah pertanian dapat menjamin keberlangsungan usaha ternak perah dan meningkatkan produksi susunya. Pada peternakan 'Nursi' ini terdapat 12 ekor sapi perah Fries Holland (FH), 8 ekor laktasi dan 4 ekor kering kandang dengan bobot badan rata-rata $350 \mathrm{~kg}$. Rata-rata produksi susu $14 \mathrm{~L} / \mathrm{ekor} /$ hari, produksi dangke 15 buah/hari dan krupuk dangke 59 bungkus/hari, dengan rata-rata jumlah pendapatan bersih total perbulannya sekitar 20 juta rupiah. Dengan melakukan kombinasi pemberian pakan asal limbah pertanian/industri tersebut dengan pakan basal rumput gajah, usaha peternakan sapi perah dan olahan susu Nursi ini sangat berpotensi untuk menjamin kesejahteraan keluarga peternak khususnya. Informasi ini akan sangat bermanfaat bagi keberlangsungan usaha peternakan sapi perah dan kesejahteraan masyarakat Kecamatan Enrekang, Kabupaten Enrekang pada umumnya.
\end{abstract}

Kata kunci: Ternak perah, ampas tahu, jerami jagung, dangke

\begin{abstract}
This paper is a field report of the utilization of agricultural by-products, tofu waste and corn straw, as feed alternative on a dairy cow farm 'Nursi' in Kecamatan Enrekang, Kabupaten Enrekang. This field report aimed to find out how effective the agricultural by-products in sustaining the dairy cow industry in this district. There are 12 dairy cows in this farm 'Nursi', with 8 lactating cows and 4 cows in dry period. Milk production was averagely $14 \mathrm{~L} /$ head/day, 'Dangke' production was 15 pieces/day and 'Dangke' crackers was 59 packs/day with the average total monthly income around twenty million
\end{abstract}


rupiahs. This indicated that the agricultural by-products is effective to be developed in the district and that this business is able to financially support the life of the local farmers in the district.

Keywords: dairy cow, tofu waste, corn straw, 'Dangke'

\section{PENDAHULUAN}

Prospek usaha ternak sapi perah di Indonesia cukup baik dan menjanjikan dilihat dari besarnya jumlah susu sapi yang masih diimpor sejalan dengan peningkatan permintaan konsumen. Berdasarkan data dari Badan Pusat Statistik, populasi sapi perah di Indonesia tahun 2019 adalah 561,061 ekor dengan produksi 996,442,44 ton susu segar dan populasi sapi perah pada tahun 2019 di Sulawesi Selatan berada pada angka 1,833 ekor dengan produksi 3,299,40 ton susu segar. Populasi sapi perah ini mengalami peningkatan 10\% dibanding tahun 2016 yang tentu saja juga mempengaruhi jumlah total produksi susu segar (BPS, 2019).

Kabupaten Enrekang termasuk dalam salah satu wilayah dalam provinsi Sulawesi Selatan yang secara astronomis terletak pada $3^{\circ} 14^{\prime} 36^{\prime \prime}-3^{\circ} 50^{\prime} 00^{\prime \prime}$ LS dan $119^{\circ} 40^{\prime} 53^{\prime \prime}-120^{\circ} 06^{\prime}$ 33" BT dan berada pada ketinggian $442 \mathrm{mdpl}$, dengan luas wilayah sebesar $1.786,01 \mathrm{~km}^{2}$. Kabupaten Enrekang berbatasan dengan Tana Toraja di sebelah utara, disebelah timur berbatasan dengan kabupaten Luwu dan Sidrap, di sebelah selatan berbatasan dengan kabupaten Sidrap dan di sebelah barat berbatasan dengan kabupaten Pinrang. Kecamatan Enrekang merupakan salah satu kecamatan yang letaknya berada di ibukota Enrekang.

Subsektor peternakan di kecamatan Enrekang kabupaten Enrekang merupakan salah satu potensi alam yang dimiliki oleh daerah tersebut yang menjadi pemasok kebutuhan masyarakat akan protein hewani, baik itu kebutuhan masyarakat setempat maupun untuk di daerah luar. Perkembangan peningkatan populasi sapi perah di kabupaten Enrekang rata-rata populasi sapi perah meningkat 131 ekor setiap tahun. Peran sapi perah dalam agribisnis pertanian cukup menonjol dibanding sapi potong, sehingga masyarakat lebih memilih memelihara sapi perah karena menghasilkan air susu sebagai bahan baku pembuatan dangke yang merupakan makanan tradisonal kabupaten Enrekang (Badan Pusat Statistik, 2017).

Pakan utama ternak ruminansia adalah hijauan yaitu sekitar $60-70 \%$, akan tetapi karena ketersediaan pakan hijauan sangat terbatas maka pemberian pakan pada peternakan 
sapi perah di kecamatan Enrekang disubstitusi dengan jerami jagung, sementara untuk sumber konsentratnya adalah dedak padi dan ampas tahu. Hal ini tidak hanya bermanfaat mengurangi pencemaran lingkungan misalnya yang diakibatkan oleh menumpuknya limbah pertanian, emisi gas rumah kaca dan juga berkurangnya hara tanah akibat pembakaran jerami, tetapi juga diharapkan dapat meningkatkan produktivitas ternak perah.

\section{METODE}

Kegiatan ini dilakukan pada tanggal 1 September - 30 September 2020, di peternakan sapi perah dan olahan susu 'Nursi' yang merupakan percontohan peternak perah di kecamatan Enrekang. Pengambilan data dilakukan melalui proses wawancara dengan pemilik usaha dan terlibat langsung dalam penyusunan ransum, serta pengolahan pakan asal limbah pertanian yaitu dedak, ampas tahu dan jerami jagung. Terdapat 12 ekor sapi perah (FH) dengan rincian 8 ekor laktasi dan 4 ekor kering kandang dengan rata-rata bobot badan 350 kg. Hijauan diberikan $10 \%$ dari bobot badan ternak dan konsentrat (campuran ampas tahu dan dedak) diberikan sekitar 3-4\% dari bobot badan ternak. Semua sumber hijauan termasuk jerami jagung diperoleh di sekitar lokasi peternakan. Ampas tahu dan dedak diperoleh dari kabupaten Pinrang dengan jarak tempuh dari lokasi peternakan sekitar 1.5 jam (43 km).

Jenis pakan dan metode pemberian dapat dilihat pada Tabel 1.

Tabel 1. Jenis pakan dan metode pemberian pakan pada usaha peternakan sapi perah dan olahan susu 'Nursi' di kecamatan Enrekang, kabupaten Enrekang

\begin{tabular}{|c|c|c|c|c|}
\hline No & Jenis Pakan & Pengolahan & $\begin{array}{l}\text { Waktu pemberian } \\
\text { (Wita) }\end{array}$ & Metode pemberian \\
\hline 1 & Rumput gajah & Segar, cacah & Jam 7.00 dan jam 17.00 & $\begin{array}{l}\text { Pakan basal, } 1 \text { jam setelah } \\
\text { pemerahan }\end{array}$ \\
\hline 2 & Rumput jepang & Segar, cacah & $\begin{array}{l}\text { Jam } 7.00 \text { dan jam } 17.00 \\
\text { (alternatif) }\end{array}$ & $\begin{array}{l}\text { Pakan basal alternatif, } \\
\text { diberikan } 1 \text { jam setelah } \\
\text { pemerahan }\end{array}$ \\
\hline 3 & Jerami jagung & Kering, cacah & $\begin{array}{l}\text { Jam } 7.00 \text { dan jam } 17.00 \\
\text { (alternatif) }\end{array}$ & $\begin{array}{l}\text { Substitusi pakan basal saat } \\
\text { stok rumput tidak mencukupi }\end{array}$ \\
\hline 4 & Ampas tahu & Segar & Jam 5.00 dan jam 15.00 & $\begin{array}{l}\text { Dicampur dengan dedak, } \\
\text { diberikan } 1 \text { jam sebelum } \\
\text { pemerahan }\end{array}$ \\
\hline 5 & Dedak & Segar & Jam 5.00 dan jam 15.00 & $\begin{array}{l}\text { Dicampur dengan ampas } \\
\text { tahu, diberikan } 1 \text { jam sebelum } \\
\text { pemerahan }\end{array}$ \\
\hline 6 & Garam & NA & Secukupnya & \\
\hline
\end{tabular}




\section{HASIL DAN PEMBAHASAN}

Efektifitas ampas tahu dan jerami jagung terhadap produktivitas ternak perah di lokasi kegiatan yang meliputi jumlah produksi susu dan olahan susu disajikan pada Tabel 2.

Tabel 2. Jumlah produksi susu dan olahan susu pada usaha peternakan sapi perah dan olahan susu 'Nursi' kecamatan Enrekang, kabupaten Enrekang

\begin{tabular}{ccc}
\hline No & Jenis Produksi & Jumlah Produksi/hari \\
\hline 1 & Susu segar & $14 \mathrm{~L} /$ ekor \\
2 & Dangke & 15 buah \\
3 & Keripik Dangke & 57 bungkus \\
\hline
\end{tabular}

Saat persediaan hijauan segar (rumput) tidak mencukupi kebutuhan ternak perah, maka penggunaan hijauan disubstitusi dengan jerami jagung. Tidak terdapat perbedaan produksi susu pada saat hijauan rumput disubstitusi dengan jerami jagung, tetapi saat ternak tidak mendapatkan asupan konsentrat jumlah produksi susu menurun sekitar $20 \%$. Adapun jumlah rataan biaya yang dikeluarkan serta pendapatan rata-rata perbulan dapat dilihat pada Tabel 3.

Pakan untuk sapi perah yang sedang laktasi terdiri atas hijauan dan konsentrat. Kuantitas dan kualitas hijauan sebagai sumber pakan serat akan mempengaruhi kadar lemak susu, karena tinggi rendahnya kadar lemak susu tergantung dari kandungan serat kasar dalam pakan ternak (Arora, 1995).

Pada usaha peternakan sapi perah di kecamatan Enrekang kabupaten Enrekang ini, jerami jagung dapat mensubstitusi pakan basal saat ketersediaan hijauan segar menipis. Jerami jagung merupakan limbah yang masih belum banyak termanfaatkan oleh peternak. Jerami jagung yang digunakan berupa daun, batang dan juga tongkol jagung, pengolahannya sangat mudah, hanya dikeringkan saja lalu dicacah, selanjutnya disimpan sebagai stok di gudang pakan. Tempat penyimpanan dan ruang penyimpanan harus memenuhi standar agar kondisi jerami tetap kering dan terhindar dari cemaran fisik, kimia maupun biologi.

Cara pengawetan ini sangat sederhana dan tidak menggunakan bahan tambahan/pelengkap. Pengawetan cara ini tidak menambah nilai nutrisi jerami jagung, 
tetapi hanya membuat daya simpan lebih lama. Meskipun tidak menambah nilai nutrisi, tetapi jerami jagung ini bisa dijadikan alternatif pakan serat. Akan tetapi, jerami jagung ini akan lebih efektif untuk ternak apabila difermentasi dengan menggunakan bahan-bahan pelengkap yang selain bisa menambah kandungan nutrisinya, juga bisa menambah palatabilitas ternak. Sebagai contoh, penambahan nilai nutrisi dari jerami jagung bisa dilakukan dengan teknik silase yaitu dengan pola fermentasi bisa dengan menggunakan dedak, pollard ataupun molasses (Trisnadewi dkk., 2017). Penggunaan bahan pelengkap ini tentu saja harus disesuaikan dengan ketersediaan di lokasi ataupun kemudahan mengakses bahan tersebut.

Tabel 3. Rincian pendapatan rata-rata perbulan usaha peternakan sapi perah dan olahan susu 'Nursi' kecamatan Enrekang, kabupaten Enrekang

\begin{tabular}{|c|c|c|}
\hline \multirow{2}{*}{$\begin{array}{l}\text { No } \\
1\end{array}$} & Jenis Biaya & Cost \\
\hline & $\begin{array}{l}\text { Biaya variable: } \\
\text { Hijauan (rumput dan Jerami jagung) } \\
\text { Konsentrat: } \\
\text { Ampas tahu } \\
\text { Dedak } \\
\text { Garam } \\
\text { Obat dan vitamin } \\
\text { Listrik dan BBM } \\
\text { Lain-lain }\end{array}$ & $\begin{array}{l}\text { Rp. 3,000,000,- } \\
\text { Rp. 1,350,000,- } \\
\text { Rp. } 100,000,- \\
\text { Rp. } 87,000,- \\
\text { Rp. } 1,000,000,- \\
\text { Rp. } 150,000,-\end{array}$ \\
\hline 2 & $\begin{array}{l}\text { Biaya tetap: } \\
\text { Penyusutan kandang: } \\
\text { 2/48 x Rp. 15,000,000,- } \\
\text { Penyusutan peralatan: } \\
\text { 2/12 x Rp. 1,000,000,- }\end{array}$ & $\begin{array}{l}\text { Rp. } \quad 625,000,- \\
\text { Rp. } \quad 166,000,-\end{array}$ \\
\hline & $\begin{array}{l}\text { Total biaya operasional: } \\
\text { Biaya variable + biaya tetap }\end{array}$ & Rp. $\quad 6.478,000,-$ \\
\hline 3 & $\begin{array}{l}\text { Produksi rata-rata: } \\
\text { Dangke } \\
\text { Harga jual } 1 \text { dangke Rp. 25,000,- } \\
15 \text { dangke/hari = Rp. 375,000,- } \\
\text { Harga jual dangke sebulan } \\
\text { Harga jual kripik dangke } \\
1776 \text { bungkus/bulan, @Rp. 10,000,- }\end{array}$ & $\begin{array}{l}\text { Rp. } 11,420,000,- \\
\text { Rp. } 17,760,000,-\end{array}$ \\
\hline & $\begin{array}{l}\text { Total Penerimaan dari hasil produksi } \\
\text { Income rata-rata/bulan }= \\
\text { Total penerimaan - Total biaya operasional }\end{array}$ & $\begin{array}{l}\text { Rp. } 29,180,000,- \\
\text { Rp. } 22,702,000,-\end{array}$ \\
\hline
\end{tabular}

Saat ternak perah tidak mengkonsumsi pakan konsentrat, maka akan sangat mempengaruhi kuantitas dan kualitas produksi susu. Pakan ternak perah yang memiliki konsentrat dalam jumlah yang tinggi akan meningkatkan produksi susu (Riski et.al., 2016). 
Pada usaha peternakan sapi perah ini, konsentrat yang diberikan adalah konsentrat basah. Ampas tahu basah memiliki kadar air yang sangat tinggi sehingga menyebabkan tidak tahan lama untuk disimpan. Selain itu kandungan nutrisi ampas tahu basah juga lebih rendah dari ampas tahu kering (Suprapti, 2005). Meskipun idealnya konsentrat kering itu lebih efektif dibanding konsentrat basah dalam meningkatkna produksi susu, ternyata tidak terdapat perbedaan yang nyata pada jumlah produksi susu dan efisiensi produksi susu (Sidqi dkk., 2014).

\section{KESIMPULAN}

Pemberian pakan asal limbah pertanian dapat menjamin keberlangsungan usaha peternaan sapi perah dan sekaligus meningkatkan produksi susu, ditambah lagi pakan limbah ini dapat dijadikan sebagai pakan alternative. Penelitian lebih lanjut perlu dilakukan untuk mellihat sejauh mana efisiensi produksi susu dan kandungan nutrisi susu dari pakan asal limbah pertanian/agroindustri.

\section{DAFTAR PUSTAKA}

Arora S.P. 1995. Pencernaan Mikroba pada Ruminansia. Yogyakarta. UGM Press.

Badan Pusat Statistik Sulawesi Selatan. 2019. Propinsi Sulawesi Selatan dalam angka. https://sulsel.bps.go.id/publication/2019/08/16 diakses tanggal 18 November 2020.

Nappu, M.B. 2013. Sebaram potensi limbah tanaman padi dan jagung serta pemanfaatannya di Sulawesi Selatan. Seminar Nasional Inovasi Teknologi Pertanian.

Riski P., Purwanto B.P., dan Atabany, A. 2016. Produksi dan Kualitas Susu Sapi FH Laktasi yang diberi Pakan Daun Pelepah Sawit. Jurnal Ilmu Produksi dan Teknologi Hasil Peternakan, 4 (3), 345-349

Sidqi, R., Makin, M., dan Suharwanto, D. 2014. Pengaruh pemberian konsentrat basah dan kering terhadap efisiensi produksi susu dan efisiensi ransum terhadap sapi perah peranakan FH. Student e-Journal, 3 (4), 1-10.

Suprapti, M.L. 2005. Pembuatan Tahu. Kanisius. Yogyakarta.

Trisnadewi, A.A.A.S., Cakra., I.G.L.O., dan Suarna, I.W. 2017. Kandungan nutrisi silase jerami jagung melalui fermentasi pollard dan molases. Majalah Ilmiah Peternakan, 20 ( 2), 55-59. 